\title{
Analysis of the factors motivating HCV-infected patients to accept interferon therapy
}

Yumiko Nagao ${ }^{1 * \dagger}$ and Michio Sata ${ }^{1,2+}$

\begin{abstract}
Background: The aims of this study were to analyze factors motivating the acceptance of interferon (IFN) therapy and to clarify the prevalence of oral mucosal diseases in hepatitis C virus (HCV)-infected Japanese patients treated with IFN.

Findings: A total of $94 \mathrm{HCV}$-infected patients who were admitted to our hospital for IFN therapy were asked questions regarding their motivation to accept IFN therapy and were investigated for the presence of oral lichen planus (OLP) before and during IFN treatment. Recommendation and encouragement from other people were the most common factors motivating the acceptance of IFN therapy (49/94, 52.13\%). The other motivators were independent decision (30.85\%), economic reasons (5.32\%), and others. According to multivariate analysis, three factors - sex (male), retreatment after previous IFN therapy, and independent decision to accept IFN therapy - were associated with patients after curative treatment of hepatocellular carcinoma (HCC). The adjusted odds ratios for these three factors were $26.06,14.17$, and 8.72 , respectively. The most common oral mucosal lesions included OLP in 11 cases (11.70\%). One patient with OLP had postoperative squamous cell carcinoma of the tongue. The rate of sustained virological response (SVR) was $45.45 \%$ in cases with OLP and $54.55 \%$ in cases without OLP. There were no patients who discontinued IFN therapy because of side effects such as oral mucosal diseases.
\end{abstract}

Conclusions: We should give full explanation and recommend a course of treatment for a patient to accept IFN therapy. The system to support liver disease as well as oral diseases is also necessary for patient treated for IFN therapy.

Keywords: Hepatitis C virus, Interferon therapy, Chronic hepatitis C, Hepatocellular carcinoma, Oral lichen planus

\section{Findings}

\section{Background}

Japanese hepatitis $\mathrm{C}$ virus (HCV)-infected patients tend to be older than those in other countries and their older age favors the onset of hepatocellular carcinoma (HCC), leading to an increased mortality rate [1,2]. The number of deaths from HCC continues to rise in Japan, where about $80 \%$ of $\mathrm{HCC}$ are caused by $\mathrm{HCV}$ and $10 \%$ by hepatitis B virus (HBV) [1,2].

Interferon (IFN) therapy for chronic hepatitis $\mathrm{C}$ is the only treatment that enables complete elimination of the virus. In recent years, pegylated IFN (Peg-IFN) and ribavirin (RBV) combination therapy has been the

\footnotetext{
* Correspondence: nagao@med.kurume-u.ac.jp

${ }^{\dagger}$ Equal contributors

'Department of Digestive Disease Information \& Research, Kurume University School of Medicine, 67 Asahi-machi, Kurume, Fukuoka 830-0011, Japan

Full list of author information is available at the end of the article
}

standard treatment for chronic hepatitis C. It has been shown that IFN therapy contributes to the prevention of occurrence of $\mathrm{HCC}$ and to improvement in longterm prognosis [3-6]. In view of the current circumstances, Japan's Ministry of Health, Labor and Welfare introduced in April 2008 a support system for medical costs for $\mathrm{HCV}$ and $\mathrm{HBV}$ carriers receiving IFN therapy [7].

We reported previously factors interfering with the acceptance of IFN therapy by HCV-infected patients at eight facilities (clinics/hospitals) [8,9]. Why is IFN therapy not used more widely for treatment of HCV carriers in Japan? Multivariate analysis demonstrated that treatment facilities, sex and the presence or absence of complications were factors associated with the risk that patients would decline IFN therapy. Female patients were more likely than male patients to decline IFN

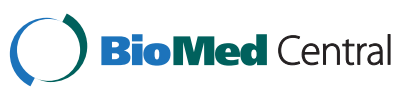


therapy because of worries about the adverse effects of the therapy.

The sustained virological response (SVR) rate after 48 weeks of Peg-IFN/RBV therapy at the standard dose is approximately 40 to $50 \%$, while the frequency of adverse events in combination therapy with Peg-IFN/RBV is relatively high (20-64\%) [10-12]. Among the side effects of IFN therapy, oral lesions might be easy to be overlooked and, among the side effects in a Japanese Phase III trial of Peg-IFN/RBV, oral mucosal disease and dental problems have been documented in patients with chronic hepatitis $\mathrm{C}$.

$\mathrm{HCV}$ infection is associated with several clinical and biological extrahepatic manifestations [13]. These include hematologic diseases such as cryoglobulinemia and lymphoma, renal diseases such as membranoproliferative glomerulonephritis, autoimmune disorders such as thyroiditis, and dermatologic conditions such as lichen planus (LP) and porphyria cutanea tarda.

In the present study, we analyzed the factors motivating the acceptance of IFN therapy and investigated the development of oral mucosal disease at the time of IFN therapy of HCV-infected patients.

\section{Methods}

Patients

A total of $94 \mathrm{HCV}$-infected patients who were admitted to the Kurume University Hospital from October 2009 to September 2011 for treatment with IFN monotherapy, Peg-IFN monotherapy or Peg-IFN/RBV combination therapy were studied (Table 1). All patients were admitted in order to achieve sustained eradication of HCV. Seventy-two patients had not received previous interferon therapy and 22 had relapsed after previous IFN therapy. The 94 patients were 58 men and 36 women with a mean age of $57.01 \pm 11.55$ years. There were 9 patients ( 8 men and one woman) with histories of curative treatment for HCV-related HCC. They had been monitored carefully for relapse over a year or more. Exclusion criteria of this study were patients with longterm maintenance IFN therapy and participants in a clinical trial.

According to the clinical pathway, all patients had checkups for oral mucosal diseases in the Digestive Diseases Center at our Hospital. In this Digestive Diseases Center, physicians, surgeons, radiologists and an oral surgeon examine each patient in their own specialized

Table 1 Characteristics of the 94 patients

\begin{tabular}{|c|c|c|c|}
\hline Characteristics & & $\mathrm{n}$ & $\%$ \\
\hline Sex & male / female & $36 / 58$ & \\
\hline Age & $($ mean $\pm S D)$, years & $57.01 \pm 11.55$ & \\
\hline \multirow[t]{6}{*}{ Age groups } & 20-29 years & 3 & $3.19 \%$ \\
\hline & $30-39$ years & 5 & $5.32 \%$ \\
\hline & 40-49 years & 15 & $15.96 \%$ \\
\hline & $50-59$ years & 22 & $23.40 \%$ \\
\hline & $60-69$ years & 38 & $40.43 \%$ \\
\hline & 70-79 years & 11 & $11.70 \%$ \\
\hline \multirow[t]{2}{*}{ Employment } & unemployed & 42 & $44.68 \%$ \\
\hline & employed & 52 & $55.32 \%$ \\
\hline \multirow[t]{3}{*}{ Diagnosis of liver disease } & $\mathrm{AH}-\mathrm{C}$ & 1 & $1.06 \%$ \\
\hline & $\mathrm{CH}-\mathrm{C}$ (after HCC treatment) & $87(5)$ & $92.55 \%$ \\
\hline & LC-C (after HCC treatment) & $6(4)$ & $6.38 \%$ \\
\hline \multirow[t]{7}{*}{ IFN therapy } & IFN beta monotherapy & 1 & $1.06 \%$ \\
\hline & $\begin{array}{l}\text { IFN beta induction therapy followed Peg-IFN } \\
\text { alpha } 2 \mathrm{~b} / \mathrm{RBV}\end{array}$ & 12 & $12.77 \%$ \\
\hline & Peg-IFN alpha 2b/RBV & 60 & $63.83 \%$ \\
\hline & Peg-IFN alpha 2a/RBV & 11 & $11.70 \%$ \\
\hline & Peg-IFN alpha 2a monotherapy & 7 & $7.45 \%$ \\
\hline & $\begin{array}{l}\text { Peg-IFN alpha } 2 \mathrm{~b} / \mathrm{RBV} \rightarrow \text { Peg-IFN alpha } 2 \mathrm{a} \\
\text { monotherapy }\end{array}$ & 2 & $2.13 \%$ \\
\hline & $\begin{array}{l}\text { Peg-IFN alpha } 2 \mathrm{~b} / \mathrm{RBV} \rightarrow \text { Peg-IFN alpha } 2 \mathrm{a} \\
\text { monotherapy } \rightarrow \text { Peg-IFN alpha 2a/RBV }\end{array}$ & 1 & $1.06 \%$ \\
\hline
\end{tabular}


Table 2 Factors motivating the acceptance of IFN therapy

\begin{tabular}{|c|c|c|c|c|c|c|c|}
\hline & \multirow[t]{2}{*}{ Question items } & \multicolumn{2}{|c|}{ Multiple answers } & \multicolumn{2}{|c|}{ Only answer } & \multicolumn{2}{|c|}{ Only answer } \\
\hline & & $\mathbf{n}$ & $\%$ & $\mathbf{n}$ & $\%$ & $\mathbf{n}$ & $\%$ \\
\hline \multirow{6}{*}{$\begin{array}{l}\text { Recommendation and } \\
\text { encouragement from } \\
\text { other people }\end{array}$} & Recommendation from a primary care doctor & 62 & $65.96 \%$ & 18 & $19.15 \%$ & 49 & $52.13 \%$ \\
\hline & Recommendation from a hepatologist & 71 & $75.53 \%$ & 18 & $19.15 \%$ & & \\
\hline & With family's encouragement & 40 & $42.55 \%$ & 8 & $8.51 \%$ & & \\
\hline & $\begin{array}{l}\text { With the encouragemant of friends and } \\
\text { acquaintances }\end{array}$ & 15 & $15.96 \%$ & 4 & $4.26 \%$ & & \\
\hline & $\begin{array}{l}\text { With encouragement from a government } \\
\text { office and healthcare center }\end{array}$ & 2 & $2.13 \%$ & 0 & $0.00 \%$ & & \\
\hline & $\begin{array}{l}\text { With encouragement from a patient advocacy } \\
\text { group for liver disease }\end{array}$ & 1 & $1.06 \%$ & 1 & $1.06 \%$ & & \\
\hline \multirow[t]{2}{*}{ Independent decision } & $\begin{array}{l}\text { Overcoming an illness by patient's own } \\
\text { determination }\end{array}$ & 79 & $84.04 \%$ & 20 & $21.28 \%$ & 29 & $30.85 \%$ \\
\hline & Hope of longevity for the pateint and his family & 66 & $70.21 \%$ & 9 & $9.57 \%$ & & \\
\hline \multirow[t]{2}{*}{ Economic reasons } & $\begin{array}{l}\text { Reducing hepatitis virus-infected patient's cost } \\
\text { of medical care in the Japanese medical system } \\
\text { from the beginning of } 2008 \text {. }\end{array}$ & 51 & $54.26 \%$ & 4 & $4.26 \%$ & 5 & $5.32 \%$ \\
\hline & $\begin{array}{l}\text { Coping with lower income before the official } \\
\text { retirement age }\end{array}$ & 1 & $1.06 \%$ & 1 & $1.06 \%$ & & \\
\hline \multirow{2}{*}{$\begin{array}{l}\text { Outcome of same } \\
\text { diseases from the } \\
\text { people nearest }\end{array}$} & $\begin{array}{l}\text { Awareness of people such as family and friends } \\
\text { who have recovered from illness }\end{array}$ & 9 & $9.57 \%$ & 2 & $2.13 \%$ & 5 & $5.32 \%$ \\
\hline & $\begin{array}{l}\text { Awareness of death in the family and friends } \\
\text { having the same liver diseases }\end{array}$ & 12 & $12.77 \%$ & 3 & $3.19 \%$ & & \\
\hline \multirow[t]{3}{*}{ Increased leisure time } & $\begin{array}{l}\text { Devotion of certain amounts of time to the } \\
\text { treatment of liver disease by reason of retirement } \\
\text { and corporate downsizing }\end{array}$ & 12 & $12.77 \%$ & 2 & $2.13 \%$ & 3 & $3.19 \%$ \\
\hline & $\begin{array}{l}\text { Devotion of certain amounts of time to the } \\
\text { treatment of liver disease free of elders who } \\
\text { need care and student taking an entrance exam }\end{array}$ & 25 & $26.60 \%$ & 0 & $0.00 \%$ & & \\
\hline & Coordination of work schedules to receive the treatment & 34 & $36.17 \%$ & 1 & $1.06 \%$ & & \\
\hline \multirow{5}{*}{$\begin{array}{l}\text { Gathering medical } \\
\text { information }\end{array}$} & Participation in seminar for liver disease with patients & 21 & $22.34 \%$ & 0 & $0.00 \%$ & 1 & $1.06 \%$ \\
\hline & Reading a newspaper, book or pamphlet & 41 & $43.62 \%$ & 0 & $0.00 \%$ & & \\
\hline & Watching a TV program & 28 & $29.79 \%$ & 1 & $1.06 \%$ & & \\
\hline & Gather information from the internet & 21 & $22.34 \%$ & 0 & $0.00 \%$ & & \\
\hline & Watching TV reports of lawsuits of hepatitis & 23 & $24.47 \%$ & 0 & $0.00 \%$ & & \\
\hline $\begin{array}{l}\text { Recovering from an } \\
\text { extrahepatic disease }\end{array}$ & $\begin{array}{l}\text { Concentratation on the treatment of liver diseases after } \\
\text { recovering from an extrahepatic disease }\end{array}$ & 7 & $7.45 \%$ & 1 & $1.06 \%$ & 1 & $1.06 \%$ \\
\hline The others & $\begin{array}{l}\text { Dislike receiving injections for liver supporting therapy } \\
\text { thrice weekly for many months }\end{array}$ & 4 & $4.26 \%$ & 1 & $1.06 \%$ & 1 & $1.06 \%$ \\
\hline
\end{tabular}

area. Each patient was advised by an oral surgeon about the presence of oral infection before commencing IFN treatment. All patients who received IFN therapy for chronic HCV liver disease at our hospital were required to undergo hospitalization for two weeks for therapeutic management and education about liver diseases. After the patients left the hospital, those who felt an uncomfortable feeling in the mouth such as reticular oral lichen planus (OLP) and xerostomia were free to consult the same oral surgeon. The study complied with the ethical guidelines of the Declaration of Helsinki. Informed consent was obtained from all patients after the purpose and methods of the study were explained.

\section{Factors motivating HCV-infected patients to accept IFN}

\section{therapy}

All patients answered the oral surgeon's questions about their motivation for accepting IFN therapy. If a physician who treats directly chronic liver disease questions a patient, bias error occurs to patient's answer. Therefore oral surgeon, member of a healthcare team interviewed to keep neutrality and equality. Specific questions based on validation reports interfering with the acceptance of IFN therapy by $\mathrm{HCV}$-infected patients [8,9], including 1 ) recommendation and encouragement from other people, 2) independent decision, 3) economic reasons, 4) outcome of same diseases in close associates, 5) increased 
leisure time, 6) gathering medical information, 7) recovering from an extrahepatic disease, and 8) the others, are listed in Table 2.

\section{Examination of oral mucosal disease}

We used the headband fiber (50-100-10, Daiichi Medical Co., Ltd.) with a brightness of 34,000 luces for mucosal examination. Oral biopsy was performed on some patients. The diagnosis of OLP was made on the basis of clinical and histopathological features. Salivary flow was measured in patients with dry mouths. We used a simple and low-cost test for detection of xerostomia and this required chewing on a piece of gauze for $2 \mathrm{~min}$. A salivary flow rate of below $2 \mathrm{~g} / 2 \mathrm{~min}$ was judged as decreased salivary secretion.

\section{Statistical analysis}

All data are expressed as mean \pm standard error. Differences between the two groups were analyzed using Wilcoxon's test. Differences were judged significant for $\mathrm{p}$ $<0.05$ (two-tailed). Adjusted odds ratios were calculated using logistic regression analysis. All statistical analyses were conducted using JMP Version 6 (SAS Institute, Cary, NC, USA). The level of statistical significance was defined as 0.05 .

\section{Results}

\section{Factors motivating why patients accepted IFN therapy}

Table 2 lists multiple answers and the principal factors motivating patients to accept IFN therapy. Of 94 patients who received IFN therapy, recommendation to them by a physician, such as a primary care doctor or hepatologist, family or a friend was the most common motivation for choosing the therapy (49 cases, 52.13\%). The other motivators were: independent decision (29/94, $30.85 \%)$, economic reasons $(5 / 94,5.32 \%)$, outcome of the same liver diseases in close associates (5/94, 5.32\%), increased leisure time $(3 / 94,3.19 \%)$, gathering medical information $(1 / 94,1.06 \%)$, and recovering from an extrahepatic disease $(1 / 94,1.06 \%)$.

The principal reasons for nine patients who had previous HCC treatment accepting IFN therapy were as follows: overcoming an illness by the patient's own determination (4 cases), hope of longevity for the patient and his family (2 cases), recommendation from a hepatologist ( 2 cases), and recommendation from a primary care doctor (1 case).

\section{Prevalence of OLP among patients with HCV infection who received IFN}

The prevalence of OLP was $11.7 \%$ (11/94). The average age of those with OLP $(62.18 \pm 6.43$ years $), 2$ men and 9 women, was greater than that of 83 non-OLP patients $(56.33 \pm 11.92$ years $)$ but there was no significant difference. The distribution of OLP according to site of occurrence was: buccal mucosa 11 (100\%), tongue 3 (27.27\%), lower lip 2 (18.18\%), gingiva 1 (9.09\%), oral floor 1 (9.09\%), and soft palate 1 (9.09\%), among 19 sites in 11 patients (Table 3 ). The erosive or reticular type of OLP was found in 7 (63.63\%) and 4 (36.36\%) patients, respectively. Onset of OLP was: before IFN therapy (8, $72.72 \%)$ and during IFN therapy (3, 27.27\%). Symptoms of three OLP patients with erosive type worsened during IFN treatment, but those reduced their symptoms by application of steroid. We did not need to reduce dose of IFN and/or RBV. The effect of IFN therapy in 11 OLP with patients were: SVR $(5 / 11,45.45 \%)$ and non-SVR (6/ 11, 54.55\%).

The other oral diseases were: postoperative squamous cell carcinoma of the tongue $(1 / 94,1.06 \%)$, leukoplakia of the tongue $(1 / 94,1.06 \%)$, aphthous stomatitis $(3 / 94$, $3.19 \%)$, xerostomia $(3 / 94,3.19 \%)$, oral candidosis $(2 / 94$, $2.12 \%)$, traumatic ulcer of the tongue $(1 / 94,1.06 \%)$, and oral benign tumor (3/94, 3.19\%). Two patients $(2.12 \%)$ had fissured tongue. A 57-year-old woman with OLP had a history of resection of squamous cell carcinoma of the tongue (T1N0M0, stage I) nine years previously. Three patients with xerostomia had salivary flows below the normal value (the average flow, $1.09 \pm 0.07 \mathrm{~g} / 2 \mathrm{~min}$ ).

There were no patients who discontinued IFN therapy because of side effects such as OLP and the other oral diseases. We commenced the usual therapeutic doses of IFN regardless of the presence of oral mucosal lesions.

\section{Multivariate analysis of the patients with HCC after curative treatment}

According to multivariate analysis, three factors, sex (male), retreatment after previous IFN therapy, and independent decision to accept IFN therapy, were characteristic factors of the patients after curative treatment of HCC. The adjusted odds ratios for these three factors were $26.06,14.17$, and 8.72 , respectively, and each was statistically significant (Table 4 ).

\section{Discussion}

Japan has operated a universal health insurance system since 1961. Any person who has an address in Japan must enroll for public health insurance. Based on the insurance benefits, the medical fees that an individual pays upon receiving a medical examination at a hospital, dental clinic, etc. are reduced.

It is believed that between one and two million Japanese people are chronically infected with $\mathrm{HCV}[1,2]$. In Japan, the Ministry of Health, Labor and Welfare alleviated the economic burden of therapy for diseases associated with HCV and HBV infection in April 2008 and expanded this system for the treatment of HBV carriers with nucleoside analogues in April 2010 [7]. The 
Table 3 Distribution of oral mucosal diseases with HCV-related liver diseases

\begin{tabular}{|c|c|c|c|c|c|c|c|c|c|c|c|c|c|c|c|c|c|c|}
\hline \multirow[t]{3}{*}{ No } & \multirow[t]{3}{*}{ Sex } & \multirow{3}{*}{ Age } & \multirow{3}{*}{$\begin{array}{l}\text { Liver } \\
\text { disease }\end{array}$} & \multicolumn{8}{|c|}{ Oral lichen planus } & \multirow{3}{*}{$\begin{array}{c}\text { Oral cancer } \\
(n=1) \\
\text { tongue }\end{array}$} & \multirow{3}{*}{$\begin{array}{c}\begin{array}{c}\text { Oral } \\
\text { leukoplakia }\end{array} \\
(n=1) \\
\text { tongue }\end{array}$} & \multirow{3}{*}{$\begin{array}{c}\begin{array}{c}\text { Aphthous } \\
\text { stomatitis }\end{array} \\
(n=3) \\
\end{array}$} & Xerostomia & \multirow{3}{*}{$\begin{array}{c}\begin{array}{c}\text { Oral } \\
\text { candidosis }\end{array} \\
(n=2) \\
\end{array}$} & \multirow{2}{*}{$\begin{array}{c}\begin{array}{c}\text { Traumatic } \\
\text { ulcer }\end{array} \\
(n=1)\end{array}$} & \multirow{3}{*}{$\begin{array}{l}\begin{array}{l}\text { Benign } \\
\text { tumor }\end{array} \\
(n=3) \\
\end{array}$} \\
\hline & & & & \multicolumn{8}{|c|}{$(n=11)$} & & & & $(n=3)$ & & & \\
\hline & & & & $\begin{array}{l}\text { buccal } \\
\text { mucosa }\end{array}$ & gingiva & tongue & $\begin{array}{l}\text { lower } \\
\text { lip }\end{array}$ & $\begin{array}{l}\text { oral } \\
\text { floor }\end{array}$ & $\begin{array}{c}\text { soft } \\
\text { palate }\end{array}$ & type & onset & & & & & & $\overline{\text { tongue }}$ & \\
\hline 1 & $\mathrm{~F}$ & 55 & $\mathrm{CH}-\mathrm{C}$ & $\bigcirc$ & & $\bigcirc$ & & & & erosive & $\begin{array}{l}\text { during IFN } \\
\text { therapy }\end{array}$ & & & & & & & \\
\hline 2 & $\mathrm{~F}$ & 58 & $\mathrm{CH}-\mathrm{C}$ & & & & & & & & & & & $\bigcirc$ & & & & \\
\hline 3 & M & 54 & $\mathrm{CH}-\mathrm{C}$ & O & O & O & $\bigcirc$ & & & erosive & before IFN therapy & & & & & & & \\
\hline 4 & M & 62 & $\mathrm{CH}-\mathrm{C}$ & O & & & & & $\bigcirc$ & reticular & $\begin{array}{l}\text { during IFN } \\
\text { therapy }\end{array}$ & & & & & & & \\
\hline 5 & $\mathrm{~F}$ & 66 & $\mathrm{CH}-\mathrm{C}$ & $\bigcirc$ & & & & & & erosive & before IFN therapy & & & & & & & \\
\hline 6 & M & 61 & $\mathrm{CH}-\mathrm{C}$ & & & & & & & & & & & & & & & $\bigcirc$ \\
\hline 7 & $\mathrm{~F}$ & 55 & $\mathrm{CH}-\mathrm{C}$ & $\bigcirc$ & & & & & & reticular & $\begin{array}{l}\text { during IFN } \\
\text { therapy }\end{array}$ & & & & & & & \\
\hline 8 & $\mathrm{~F}$ & 62 & $\mathrm{CH}-\mathrm{C}$ & & & & & & & & & & & & $\bigcirc$ (with fissured tongue) & & & \\
\hline 9 & $\mathrm{~F}$ & 72 & $\mathrm{CH}-\mathrm{C}$ & 0 & & & & & & erosive & before IFN therapy & & & & & & & \\
\hline 10 & $\mathrm{~F}$ & 70 & $\mathrm{CH}-\mathrm{C}$ & & & & & & & & & & & & (with fissured tongue) & & & \\
\hline 11 & M & 58 & $\mathrm{CH}-\mathrm{C}$ & & & & & & & & & & & & & & & 0 \\
\hline 12 & $\mathrm{~F}$ & 57 & $\mathrm{CH}-\mathrm{C}$ & O & & O & & $\bigcirc$ & & erosive & before IFN therapy & (post ope.) & & & & & & \\
\hline 13 & $\mathrm{~F}$ & 60 & $\mathrm{CH}-\mathrm{C}$ & & & & & & & & & & & $\bigcirc$ & & & & \\
\hline 14 & $\mathrm{~F}$ & 71 & LC-C & $\bigcirc$ & & & & & & erosive & before IFN therapy & & & & $\bigcirc$ & & & \\
\hline 15 & $\mathrm{~F}$ & 66 & $\mathrm{CH}-\mathrm{C}$ & & & & & & & & & & & & & $\bigcirc$ & & \\
\hline 16 & M & 67 & $\mathrm{CH}-\mathrm{C}$ & & & & & & & & & & & O & & & & \\
\hline 17 & $\mathrm{~F}$ & 66 & $\mathrm{CH}-\mathrm{C}$ & & & & & & & & & & $\bigcirc$ & & & & & \\
\hline 18 & $\mathrm{~F}$ & 64 & $\mathrm{CH}-\mathrm{C}$ & $\bigcirc$ & & & $\bigcirc$ & & & erosive & before IFN therapy & & & & & & & \\
\hline 19 & $\mathrm{~F}$ & 61 & $\mathrm{CH}-\mathrm{C}$ & $\bigcirc$ & & & & & & reticular & before IFN therapy & & & & & & & \\
\hline 20 & $\mathrm{~F}$ & 29 & $\mathrm{CH}-\mathrm{C}$ & & & & & & & & & & & & & & $\bigcirc$ & \\
\hline 21 & $\mathrm{~F}$ & 67 & $\mathrm{CH}-\mathrm{C}$ & 0 & & & & & & reticular & before IFN therapy & & & & & & & \\
\hline 22 & $\mathrm{~F}$ & 49 & $\mathrm{CH}-\mathrm{C}$ & & & & & & & & & & & & & 0 & & \\
\hline 23 & M & 48 & $\mathrm{CH}-\mathrm{C}$ & & & & & & & & & & & & & & & 0 \\
\hline
\end{tabular}

CH-C: chronic hepatitis C, LC-C: HCV-related liver cirrhosis, IFN: interferon therapy, ope: operation. 
Table 4 Multivariate analysis of the patients with HCC after curative treatment

\begin{tabular}{lccc}
\hline & & $\begin{array}{c}\text { Adjusted odds ratio } \\
\text { (95\% confidence interval) }\end{array}$ & $\begin{array}{c}\text { P } \\
\text { value }\end{array}$ \\
\hline Sex (male) & 26.06 & $(3.44-605.65)$ & 0.0078 \\
Retreatment after previous IFN therapy & 14.17 & $(2.38-127.99)$ & 0.0068 \\
Independent decision to accept IFN therapy & 8.72 & $(1.47-77.00)$ & 0.0257 \\
\hline
\end{tabular}

program is seen as one way of reducing the cost of medical care in the Japanese medical system for patients infected with hepatitis B and C viruses. Medical care certificates for receipt of IFN therapy were issued to 44,731 people from April 2008 to May 2009. The certificates were issued to 26,594 people from April 2009 to May 2010. The certificates to receive IFN therapy and to receive nucleoside analogues therapy were issued to 28,797 and 38,038 people, respectively, from April 2010 to May 2011.

In this study, I believe we were able to collect unbiased answers from the subjects because the oral surgeon who questioned the patients was not involved directly with IFN treatment. Most of the motivators for patients to receive IFN therapy were recommendation and encouragement from a physician such as primary care doctor, rather than economic reasons. Firstly patients sought to gather information about liver disease from newspapers, the internet, etc. Subsequently, patients finally accepted, IFN therapy after they were satisfied with the explanations from their doctor. The patients who had received curative treatment for HCC decided for themselves to accept IFN therapy. What should be done about the medical approach for patients who accept IFN therapy?

Medical informed consent is essential for the physician's ability to diagnose and treat patients, as well as the patient's right to accept or reject clinical evaluation, treatment, or both [14]. Patients need to participate in the informed consent process to understand the riskbenefit relationship of the proposed treatment strategy.

Previously, we analyzed the factors preventing the implementation of IFN therapy in terms of the one to one relationship between the patient and primary care physician in $\mathrm{X}$ town (adult population: 7,389), in northern Kyushu, Japan, where the prevalence of HCV infection is the highest in the country [8,9]. Of 139 patients to whom attending physicians recommended IFN therapy, $92(66.2 \%)$ agreed to receive the treatment. In contrast, $74(86.0 \%)$ of 86 hospital patients (treated by liver specialists) agreed to receive IFN therapy but only 18 (34.0\%) of 53 clinic patients (treated by non liver-specialists) did so. The difference was attributable to the intensity of the effort and the strength of the explanations or recommendations given by the physicians to the patients. In logistic regression analysis, the adjusted odds ratios on treatment facilities, sex and complications were
$18.06,3.65$, and 3.63 respectively, indicating that there were significant differences. It is also essential to devise measures to create cooperation between hospitals and clinics, and to improve communication between physicians and their patients.

$\mathrm{HCV}$ affects other organs, as well as the liver. Extrahepatic manifestations can be found in the mucosa, skin, eyes, salivary gland, joints, kidneys, and immune system. Cacoub et al. reported that $38 \%$ of patients with $\mathrm{HCV}$ infection manifested at least one extrahepatic manifestation [15]. We reported that the prevalence of mucous or cutaneous LP, type 2 diabetes mellitus, hypertension, thyroid dysfunction, and extrahepatic malignant tumor were $19.5 \%, 21.8 \%, 28.7 \%, 20.7 \%$, and $9.2 \%$, respectively [16]. LP is associated frequently with HCV infection and can be exacerbated by IFN therapy. As regards the effects of IFN therapy on LP lesions, there is a report of their improvement [17], a report of LP manifestation triggered by IFN $[18,19]$, and a report of aggravation of LP [20-23]. In long-term observation for 3 years or longer, we reported some OLP lesions (all reticular type) were improved, not only macroscopically but also in histopathologic examination [24]. The erosive type of OLP, in particular, can cause spontaneous pain during eating and tooth-brushing, while a patient is receiving IFN therapy for $\mathrm{HCV}$ infection.

Before a patient with $\mathrm{HCV}$ infection receives IFN treatment in our hospital, that patient must undergo diagnostic evaluation of the mouth, the eyes, the mental state and the circulatory disease. We reported that six of 570 patients could not commence IFN therapy despite their admission, because of dental problems such as periodontitis, pupitis, and pericoronitis [25]. Treatment of dental infections is required before the commencement of IFN therapy for $\mathrm{HCV}$ infection. A cooperative system involving the various medical specialists leads to acceptance of IFN treatment.

We have been holding regional seminars, so-called "seminar for digestive disease", since 2005 to improve understanding of digestive diseases such as liver disease and extrahepatic manifestations by patients, their families, and healthcare workers. A total of 3,776 people have attended the lectures to date. It is also important that we provide up to date knowledge of liver disease to many people. We have to understand that various factors and motivations behind behavior, which lead to 
refusal or acceptance of IFN therapy, vary greatly between individual patients and need to support the patients and their families by a specialist for each area before, during, and after treatment.

\section{Conclusions}

In conclusion, we analyzed factors motivating the acceptance of IFN therapy by HCV-infected patients and showed the importance of the effort and the strength of the explanations or recommendations given by physicians to patients. Physicians also should be aware of OLP occurrence during IFN treatment of patients with hepatitis $\mathrm{C}$.

\section{Abbreviations \\ HCV: hepatitis C virus; HBV: hepatitis B virus; CH-C: chronic hepatitis C; LC- C: liver cirrhosis type C; HCC: hepatocellular carcinoma; OLP: oral lichen planus; IFN: interferon; Peg-IFN: pegylated interferon; RBV: ribavirin; SVR: sustained virological response.}

\section{Competing interests}

The authors declare that they have no competing interests.

\section{Authors' contributions}

YN carried out most of the data collection, designed the study, and drafted the manuscript. MS contributed to data analysis. Both authors read and approved the final manuscript.

\section{Acknowledgements}

This study was supported in part by a Grant-in-Aid for Scientific Research (C) (No.22592354) from the Ministry of Education, Culture, Sports, Science and Technology of Japan.

\section{Author details}

'Department of Digestive Disease Information \& Research, Kurume University School of Medicine, 67 Asahi-machi, Kurume, Fukuoka 830-0011, Japan. ${ }^{2}$ Division of Gastroenterology, Department of Medicine, Kurume University School of Medicine, Kurume, Fukuoka 830-0011, Japan.

Received: 23 January 2012 Accepted: 24 August 2012

Published: 29 August 2012

\section{References}

1. Yoshizawa $\mathrm{H}$ : Hepatocellular carcinoma associated with hepatitis $\mathrm{C}$ virus infection in Japan: projection to other countries in the foreseeable future. Oncology 2002, 62(Suppl 1):8-17.

2. Kiyosawa K, Tanaka E: Characteristics of hepatocellular carcinoma in Japan. Oncology 2002, 62:5-7.

3. Yoshida H, Shiratori Y, Moriyama M, Arakawa Y, Ide T, Sata M, Inoue O, Yano M, Tanaka M, Fujiyama S, Nishiguchi S, Kuroki T, Imazeki F, Yokosuka O, Kinoyama S, Yamada G, Omata M: Interferon therapy reduces the risk for hepatocellular carcinoma: national surveillance program of cirrhotic and noncirrhotic patients with chronic hepatitis C in Japan. IHIT Study Group. Inhibition of Hepatocarcinogenesis by Interferon Therapy. Ann Intern Med 1999, 131:174-181.

4. Yoshida H, Arakawa Y, Sata M, Nishiguchi S, Yano M, Fujiyama S, Yamada G, Yokosuka O, Shiratori Y, Omata M: Interferon therapy prolonged life expectancy among chronic hepatitis C patients. Gastroenterology 2002 123:483-491.

5. Okanoue T, Itoh Y, Minami M, Sakamoto S, Yasui K, Sakamoto M, Nishioji K, Murakami $Y$, Kashima K: Interferon therapy lowers the rate of progression to hepatocellular carcinoma in chronic hepatitis $\mathrm{C}$ but not significantly in an advanced stage: a retrospective study in 1148 patients. Viral Hepatitis Therapy Study Group. J Hepatol 1999, 30:653-659.

6. Mazzaferro V, Romito R, Schiavo M, Mariani L, Camerini T, Bhoori S, Capussotti L, Calise F, Pellicci R, Belli G, Tagger A, Colombo M, Bonino F, Majno P: Llovet JM; HCC Italian Task Force. Prevention of hepatocellular carcinoma recurrence with alpha-interferon after liver resection in HCV cirrhosis. Hepatology 2006, 44:1543-1554.

7. Ministry of Health, Labour and Welfare: http://www.mhlw.go.jp/english/ policy/health-medical/health/index.html.

8. Nagao Y, Sata M, Suzuki F, Nobayashi H, Kawakami Y: Toward more widespread use of novel drug therapies -Current status of interferon therapy in patients with hepatitis $C$ and discussion of strategies to propagate its use. Office of Pharmaceutical Industry Research. Research Paper Series 2006, 32:1-81. in Japanese.

9. Nagao Y, Kawakami Y, Yoshiyama T, Sata M: Analysis of factors interfering with the acceptance of interferon therapy by HCV-infected patients. Med Sci Monit 2008, 14:PI45-PI52.

10. Hadziyannis SJ, Settee H Jr, Morgan TR, Balan V, Diago M, Marcellin P, Ramadori G, Bodenheimer H Jr, Bernstein D, Rizzetto M, Zeuzem S, Pockros PJ, Lin A, Ackrill AM, PEGASYS International Study Group: Peginterferonalpha 2a and ribavirin combination therapy in chronic hepatitis $\mathrm{C}$ : A randomized study of treatment duration and ribavirin dose. Ann Intern Med 2004, 140:346-355.

11. Manns MP, McHutchison JG, Gordon SC, Rustgi VK, Shiffman M, Reindollar R, Goodman ZD, Koury K, Ling M, Albrecht JK: Peginterferon alfa-2b plus ribavirin compared with interferon alfa- $2 b$ plus ribavirin for initial treatment of chronic hepatitis C: a randomized trial. Lancet 2001, 358:958-965.

12. Fried MW, Shiffman ML, Reddy KR, Smith C, Marinos G, Gonçales FL Jr, Häussinger D, Diago M, Carosi G, Dhumeaux D, Craxi A, Lin A, Hoffman J, Yu J: Peginterferon alfa-2a plus ribavirin for chronic hepatitis $C$ virus infection. N Engl J Med 2002, 347:975-982.

13. Gumber SC, Chopra S: Hepatitis C: A multifaceted disease. Review of extrahepatic manifestations. Ann Intern Med 1995, 123:615-620.

14. Paterick TJ, Carson GV, Allen MC, Paterick TE: Medical informed consent: general considerations for physicians. Mayo Clin Proc 2008, 83:313-319.

15. Cacoub P, Renou C, Rosenthal E, Cohen P, Loury I: EH manifestations associated with HCV infection. A prospective multicenter study of 321 patients. The GERMIVIC Groupe d'Etude et de Recherche en Medicine Interne et Maladies Infectieuses sur le Virus de I'Hepatite C. Medicine [Baltimore] 2000, 79:47-56.

16. Nagao $Y$, Kawasaki $K$, Sata M: Insulin resistance and lichen planus in patients with HCV-infectious liver diseases. J Gastroenterol Hepatol 2008, 23:580-585.

17. Doutre MS, Beylot C, Couzigou P, Long P, Royer P, Beylot J: Lichen planus and virus $C$ hepatitis: disappearance of the lichen under interferon alfa therapy. Dermatology 1992, 184:229.

18. Boccia S, Gamberini S, Dalla Libera M, Strumia R, Venturini D: Lichen planus and interferon therapy for hepatitis C. Gastroenterology 1993, 105:1921-1922.

19. Nagao Y, Sata M, Ide T, Suzuki H, Tanikawa K, Itoh K, Kameyama T: Development and exacerbation of oral lichen planus during and after interferon therapy for hepatitis C. Eur J Clin Invest 1996, 26:1171-1174.

20. Protzer U, Ochsendorf FR, Leopolder-Ochsendorf A, Holtermuller KH: Exacerbation of lichen planus during interferon alfa-2a therapy for chronic active hepatitis C. Gastroenterology 1993, 104:903-905.

21. Areias J, Velho GC, Cerqueira R, Barbêdo C, Amaral B, Sanches M, Massa A, Saraiva AM: Lichen planus and chronic hepatitis C: exacerbation of the lichen under interferon-alpha-2a therapy. Eur J Gastroenterol Hepatol 1996, 8:825-828

22. Grossmann Sde M, Teixeira R, de Aguiar MC, do Carmo MA: Exacerbation of oral lichen planus lesions during treatment of chronic hepatitis $C$ with pegylated interferon and ribavirin. Eur J Gastroenterol Hepatol 2008, 20:702-706

23. Nagao $Y$, Kawaguchi T, Ide T, Kumashiro R, Sata M: Exacerbation of oral erosive lichen planus by combination of interferon and ribavirin therapy for chronic hepatitis C. Int J Mol Med 2005, 15:237-241.

24. Nagao $Y$, Sata M, Suzuki H, Kameyama T, Ueno T: Histological improvement of oral Lichen planus in patients with chronic hepatitis $C$ treated with interferon. Gastroenterology 1999, 117:283-284.

25. Nagao Y, Sata M: Dental problems delaying the initiation of interferon therapy for HCV-infected patients. Virol J 2010, 17:192

doi:10.1186/1756-0500-5-470

Cite this article as: Nagao and Sata: Analysis of the factors motivating HCV-infected patients to accept interferon therapy. BMC Research Notes 2012 5:470. 